\title{
Kinetics of pulmonary immune cells, antibody responses and their correlations with the viral clearance of influenza A fatal infection in mice
}

Jin $\mathrm{Lv}^{1+}$, Yanhong Hua ${ }^{3+}$, Dan Wang ${ }^{1}$, Aofei Liu', Juan An ${ }^{1}$, Aimin $\mathrm{Li}^{1}$, Yanfeng Wang ${ }^{1}$, Xiliang Wang ${ }^{2^{*}}$, Na Jia ${ }^{2^{*}}$ and Qisheng Jiang ${ }^{1 *}$

\begin{abstract}
Fatal influenza A virus infection is a major threat to public health throughout the world. Lung macrophages and neutrophils have critical roles for both the pathogenesis and viral clearance of fatal viral infections. These are complicated by the interaction of innate immunity and adaptive immunity against viral infection. In this study, we investigated the overall kinetics of lung macrophages, neutrophils, $C D 4^{+} T$ cells, $C D 8^{+} T$ cells, $C D 38^{+}$cells, and CD138 ${ }^{+}$cells, the levels of antibody and cytokine responses, both in the early and late phases of fatal infection with A/PR/8/34 (H1N1) virus in mice. The changes in lung viral load were also evaluated. We found that pulmonary macrophages and neutrophils both accumulated in the early and late phases of fatal infections and they positively correlated with the lung and serum antibody titers, and negatively correlated with the viral load locally. The secretion of IL-6 might relate to high numbers of macrophages and neutrophils in the early infection. The work implies that pulmonary macrophages, neutrophils and the antibody response all have an essential role in virus elimination of fatal influenza A viral infection. These findings may have implications for the development of prophylactic and therapeutic strategies in fatal influenza A viral infection. Further evaluation of the cooperation among macrophages, neutrophils and antibody responses in eliminating the virus with fatal infection is needed.
\end{abstract}

Keywords: Influenza A, Fatal infection, Macrophage, Neutrophil, Antibody

\section{Introduction}

Influenza is an acute epidemic respiratory disease that results in a high rate of mortality in human beings, especially among the elderly and children. A large number of deaths due to influenza are reported every year around the world $[1,2]$. Clinically, influenza A virus is the most important virus among the three types of the influenza virus. Influenza A viruses belong to the family Orthomyxoviridae. On the basis of the antigenicity of their haemagglutinin (HA) and neuraminidase (NA) molecules, they are classified into 16 HA subtypes (H1-H16) and 9 NA subtypes $(\mathrm{N} 1-\mathrm{N} 9)$. The point mutations and reassortment

\footnotetext{
*Correspondence: snss@sina.com; jiana79_41@hotmail.com; jqs598@sina.com ${ }^{\dagger}$ Equal contributors

${ }^{2}$ State Key Laboratory of Pathogen and Biosecurity, Beijing Institute of Microbiology and Epidemiology, 20 Dong-Da Street, Fengtai District, Beijing 100071, P.R. China

'The Second Artillery General Hospital, PLA, 16 Xinjiekouwai Street, Xicheng District, Beijing 100088, China

Full list of author information is available at the end of the article
}

events of the viral genomes contribute to the emergence of new variants or strains with epidemic or pandemic potential [3]. Influenza A viruses have caused several pandemics during the last century, and continue to cause epidemics annually. The pandemic of 1918-1919 killed as many as 50 million people worldwide [4,5]. In 2009, a novel swine-origin influenza virus capable of rapid human transmission was reported. As of 4 April 2010, worldwide more than 213 countries and overseas territories or communities have reported laboratory confirmed cases of pandemic influenza H1N1 2009, including over 3200 deaths [6]. The recent report on the drug resistance to oseltamivir phosphate capsules [7] and H7N9 outbreak in China [8] have made the prevention and control of pandemic influenza more difficult. Therefore, understanding the mechanisms of increased pathogenicity of fatal influenza A viral infection is critical to optimize antiviral treatment strategies and control potential pandemics.

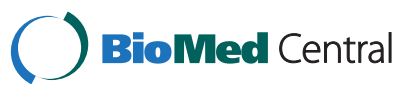


The uncontrolled and aberrant activation of the innate immune system has been implicated in the mice model of fatal influenza A viral infection [9-11]. A significantly rapid cell recruitment of macrophages and neutrophils into the lungs was assumed to have a role in the pathogenesis associated with $\mathrm{H} 5 \mathrm{~N} 1$ highly pathogenic avian influenza virus infection (HPAI) [12]. In addition, macrophages and neutrophils were associated with the increased secretion of some cytokine and chemokines [13], and increased levels of cytokines are suggested to mediate influenza A infection signs $[14,15]$. In addition, they may have a role in the severe symptoms of fatal HPAI H5N1 influenza virus infection [16-19]. However, inhibition of the cytokine response cannot protect against the lethal influenza A infection [20], and neutrophil or macrophage depletion in the early stage of infection has not had a significant effect on the outcome [13]. These findings have suggested complicated biological effects of macrophages and neutrophils in the fatal influenza A viral infection. In addition, innate immune cells such as macrophages and neutrophils, are the targets of influenza A viruses [12]. The direct infection of macrophages and neutrophils may seriously compromise the adaptive immune response.

The mouse model is very useful in the study of influenza virus pathogenesis, especially of the pneumonia by fatal infection, because the immune response and the correlations between these immune parameters in the lung can be monitored and evaluated directly. Influenza $\mathrm{A} / \mathrm{PR} / 8 / 34 \mathrm{H} 1 \mathrm{~N} 1$ virus (PR8) is a mouse-adapted influenza strain, which induced the destruction of type II pneumocytes in alveoli in the mice $[21,22]$. In addition, several researchers used PR8 as the backbone virus to generate attenuated epidemic influenza vaccines [23-26]. Therefore, a detailed description on immune responses of PR8 fatal infection in the lung of mice could both contribute to the pathogenesis understanding and provide the useful data for comparison with reassortant influenza virus vaccine with PR8 backbone. In this study, we employed PR8 viruses to investigate the kinetics of innate and adaptive cellular immune responses in a mouse model. An overall picture of immune cell activities was obtained, both for the early and late phases of the fatal infection. The local viral load was also measured and its correlations with cellular responses and antibody levels were evaluated.

\section{Materials and methods}

\section{Virus preparation}

Influenza $\mathrm{A} / \mathrm{PR} / 8 / 34(\mathrm{H} 1 \mathrm{~N} 1)$ virus was kindly provided by Dr. Yuelong-Shu (Chinese Center for Disease Control and Prevention). Ten-day-old embryonated chicken eggs were infected with $0.1 \mathrm{ml}$ of stock virus diluted to 1:1000 in PBS. After incubation for 48 hours at $35 \sim 36^{\circ} \mathrm{C}$, the allantoic fluid was collected and clarified by centrifugation at $3500 g_{\text {av }}$ for
$20 \mathrm{~min}$. Virus stocks were aliquoted and stored at $-70^{\circ} \mathrm{C}$ until use. Fifty percent tissue culture infectious dose $\left(\mathrm{TCID}_{50}\right)$ and $50 \%$ egg infectious dose $\left(\mathrm{EID}_{50}\right)$ titers were determined by serial titration of viruses in Madin-Darby canine kidney (MDCK) cells and eggs, respectively. Titers were calculated by the method of Reed and Muench.

\section{Infection of mice}

Female BALB/c mice were purchased from the Institute of Jingfeng Medical Laboratory Animal and were maintained under specific pathogen-free conditions. Five mice in each group were lightly anesthetized by ethylether inhalation and infected by intranasal inoculation (in $25 \mu \mathrm{l}$ ) of $5 \times 10^{5}$, $5 \times 10^{4}, 5 \times 10^{3}, 5 \times 10^{2}, 5 \times 10^{1}$ p.f.u. of viruses to determine the $50 \%$ lethal dose $\left(\mathrm{LD}_{50}\right)$. Plaque assays were performed on MDCK cells to titration of the viruses. Plaque Forming Units (PFU) is a measure of the number of particles capable of forming plaques per unit volume, such as virus particles. It is a functional measurement rather than a measurement of the absolute quantity of particles: viral particles that are defective or which fail to infect their target cell will not produce a plaque and thus will not be counted. One plaque forming unit means a virus or group of viruses which cause a plaque. In the following experiment, $5 \times 10^{5}$ p.f.u. viruses were used to lethal infection of 20 mice per group and eight groups were used. Mice not infected with influenza $\mathrm{A} / \mathrm{PR} / 8 / 34$ virus were used as the control group. The animal experiments were approved by the Animal Subjects Research Review Board of the Beijing Institute of Microbiology and Epidemiology and were conducted according to the institution's guidelines for animal husbandry.

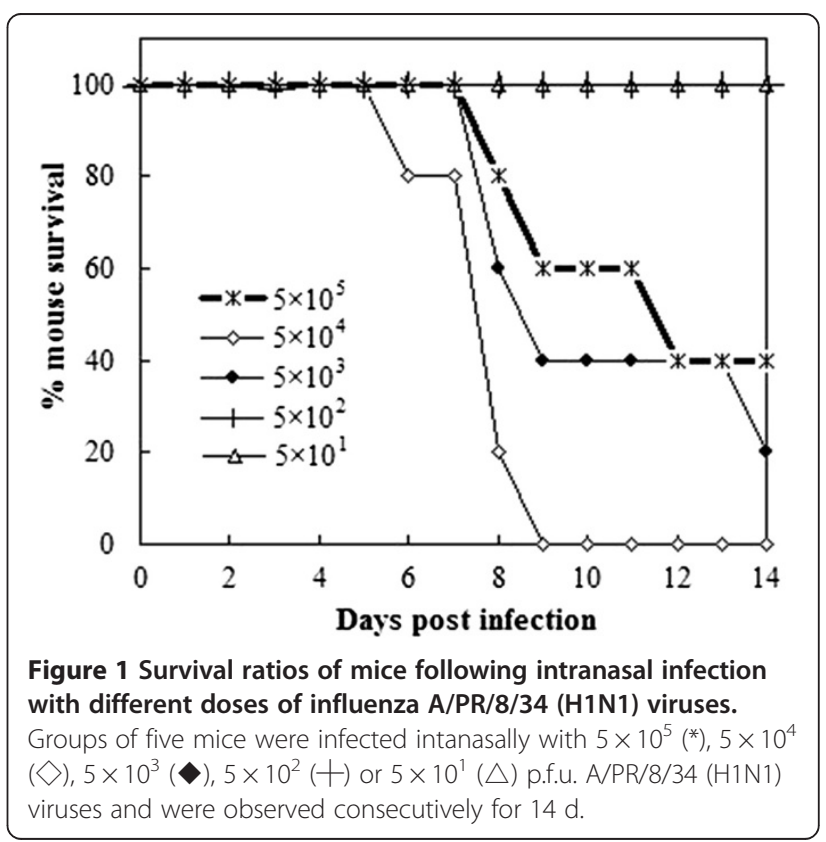




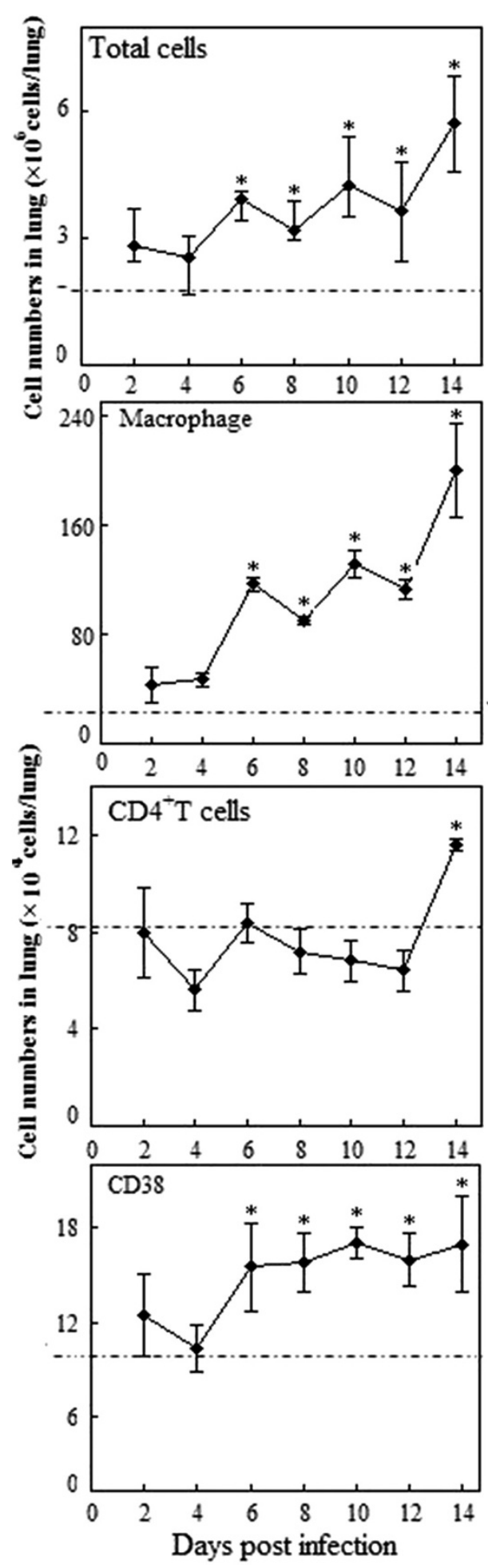

Figure 2 (See legend on next page.)

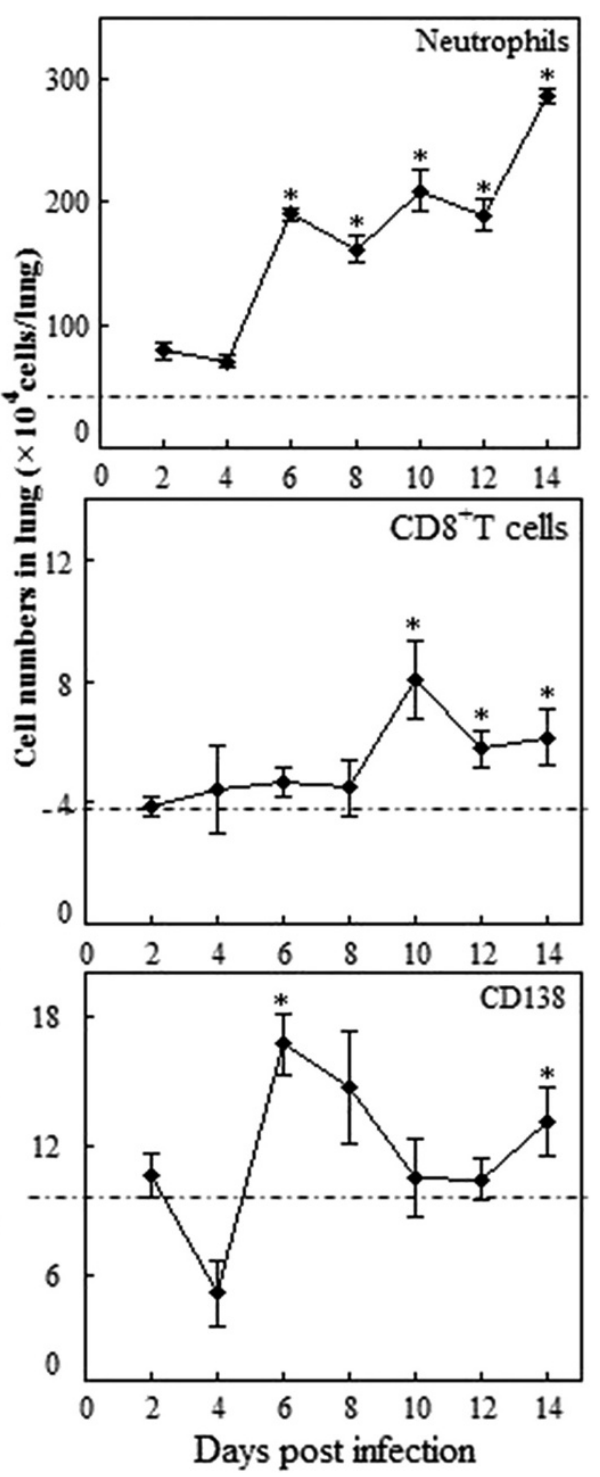


(See figure on previous page.)

Figure 2 Kinetics of pulmonary immune cells in mice with fatal dose $\left(5 \times 10^{5}\right.$ p.f.u.) of A/PR/8/34 (H1N1) virus infection. The frequencies of macrophages $\left(\mathrm{CD} 11 \mathrm{~b}^{+} / \mathrm{CD} 11 \mathrm{c}^{-} / \mathrm{Ly} 6 \mathrm{G} / \mathrm{c}^{-}\right)$and neutrophils $\left(\mathrm{CD} 11 \mathrm{~b}^{+} / \mathrm{CD} 11 \mathrm{c}^{-} / \mathrm{Ly} 6 \mathrm{G} / \mathrm{C}^{+}\right)$were determined by appropriate gating within the total lung leukocytes. For determination of the frequencies of $\mathrm{CD}^{+}$and $\mathrm{CD} 8^{+} \mathrm{T}$ cells, the $\mathrm{CD} 3^{+} \mathrm{T}$ cells were first determined by appropriate gating within the pulmonary lymphocytes, and then $\mathrm{CD} 4^{+} / \mathrm{CD} 8^{-} \mathrm{T}$ cells and $\mathrm{CD} 4^{-} / \mathrm{CD}^{+} \mathrm{T}$ cells were detected by gating within the $\mathrm{CD} 3^{+} \mathrm{T}$ cells. In the detection of frequency of $\mathrm{CD} 138^{+}$cells and $\mathrm{CD} 38^{+}$cells, B220/CD45R was used to identify different B cell subtypes within the pulmonary lymphocytes, then $\mathrm{CD} 138^{+}$and $\mathrm{CD} 38^{+} \mathrm{B}$ cells were determined by appropriate gating within the determined B cell subtype, respectively. Mice without infection were used as the control group. Mean lung cell numbers were representative of at least 3 mice lungs per time point group, and error bars indicated the standard deviations. The dotted lines were the control level. ${ }^{*} p<0.05$ compared with control group.

\section{Tissue preparation}

Individual body weights from each group were recorded and monitored daily for disease signs and death for $14 \mathrm{~d}$ post infection. On days 2, 4, 6, 8, 10, 12 and 14 post infection, 15 mice at each time point were euthanized, and lungs were collected separately and homogenized in $2 \mathrm{~mL}$ sterile PBS. After this process, homogenates were frozen separately in sterile tubes at $-80^{\circ} \mathrm{C}$ for later titration of antibody and cytokine detections. For the detection of lung immune cells, five to six mice at each time

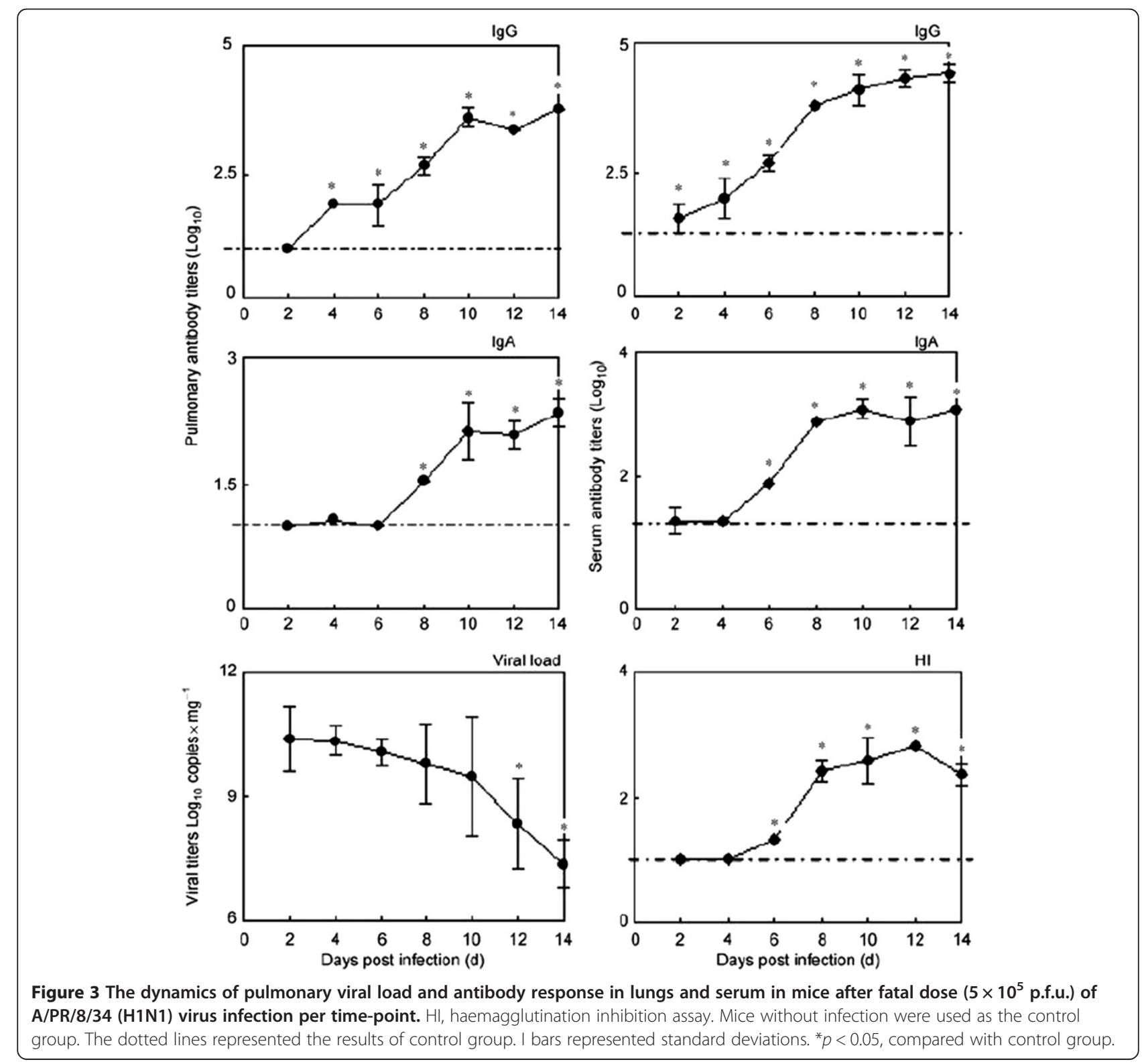


point post infection were sacrificed by cervical dislocation. The lungs were dissected and placed into cold DMEM. Lung cell preparations were made by passing tissue through a nylon screen. Red blood cells were removed by lysis buffer treatment (BD, biosciences). Cells were counted and resuspended at appropriate concentrations for each particular experiment.

\section{Flow cytometry and cytokine measurement}

Single lung cell suspensions were stained with fluorochrome-labeled anti-CD3, anti-CD4, anti-CD8, antiCD11b, anti-CD11c, anti-Ly-6G/C, anti-CD138 and antiCD38 antibodies (BD Biosciences). Cells were labeled for $45 \mathrm{~min}$ at $4^{\circ} \mathrm{C}$ in staining buffer (PBS with 1\%FBS, $0.02 \%$ NaN3), washed twice with PBS and fixed overnight at $4^{\circ} \mathrm{C}$ with $2 \%$ paraformaldehyde. Flow cytometry was performed on a FACS Aria flow cytometer (BD Biosciences). IL-6, IL-10, IL-17, IFN-үand IL-4 cytokine protein levels in the lungs were measured by specific enzyme-linked immunosorbent assay (ELISA; R\&D Systems, Minneapolis, MN, USA).

\section{RT-PCR detection of the viral load}

The viral load in the lung tissues was determined by the real-time reverse-transcriptase-polymerase-chain-reaction (RT-PCR). We extracted RNA from lung homogenates with Trizol (Invitrogen, USA) reagent. Then, reverse transcriptions targeting at a conserved region of influenza matrix $(\mathrm{M})$ gene were performed, as previously described [27].

\section{Virus-specific Antibody assays}

Influenza-specific serum and lung homogenate antibodies were measured by ELISA, using plates coated with $1 \mu \mathrm{g} / \mathrm{ml}$ per well of purified A/PR/8/34 (H1N1) influenza virus. Briefly, two-fold serial dilutions of sample (1:25 to1:3200 for IgA detection, $1: 50$ to $1: 102400$ for IgG detection) were incubated in the plates. Bound Ab was detected with HRP-conjugated goat anti-mouse Abs specific for IgG and IgA, and was developed with TMB (Sigma, USA). Absorbance was read at $450 \mathrm{~nm}$ on a BioRAD model 550 Microplate Reader. The virus-specific $\mathrm{Ab}$ titer was defined as the reciprocal of the highest sample dilution giving an absorbance value greater than twice that of the samples from the negative controls. The titers were gained in duplicate.

Haemagglutination inhibition (HI) assay was performed as previous described $[28,29]$. The HI titers were expressed as the reciprocal of the highest dilution that completely inhibited haemagglutination of erythrocyte.

\section{Statistical analysis}

Statistical differences at each time point were determined by one-way ANOVA tests. A Spearman correlation analysis was performed to detect the correlation among viral load and frequencies of different cells, and antibody titers with SPSS19.0. Values of $p<0.05$ were considered significant.

\section{Results}

To investigate the lethal dose, we inoculated intranasally six groups of mice with $5 \times 10^{5}, 5 \times 10^{4}, 5 \times 10^{3}, 5 \times 10^{2}$, $5 \times 10^{1}$ p.f.u. of the viruses. In group of dose $5 \times 10^{4}$ p.f.u., the first mouse death was observed at day 5 , and the death rate increased to $100 \%$ at day 9 post infection (Figure 1). Compared with that group, the mice in group of dose $5 \times 10^{5}$ p.f.u. began to die at day 7 , and $40 \%$ mice survived until day 14. This dose induced severe pulmonary pathology (data not show) and was thus used in the following experiments to evaluate the immune responses in the lung of fatal influenza $\mathrm{A} / \mathrm{PR} / 8$ virus infection.

\section{Comparing the kinetics of lung macrophage and neutrophils with other immune cells in lungs}

We first measured the frequency of lung macrophage, neutrophils, $\mathrm{CD}^{+} \mathrm{T}$ cells, $\mathrm{CD} 8^{+} \mathrm{T}$ cells, $\mathrm{CD} 38^{+}$cells and CD $138^{+}$cells. The results shown in Figure 2 indicated that total pulmonary cells accumulated locally in A/PR/ $8 / 34$ virus infection 6 days post infection, and kept a significant high level till 14 days post infection. Meanwhile, both the macrophages and neutrophils had a similar pattern (Figure 2). The increase of $\mathrm{CD} 4^{+} \mathrm{T}$ cell was only observed in the late infection (14 days post infection) (Figure 2), while the increase of $\mathrm{CD}^{+} \mathrm{T}$ cells was observed from day 10 to 14 days post infection. However, the frequency of lung $\mathrm{CD}_{3} 8^{+}$increased from day 6 to 14 post infection, whereas $\mathrm{CD} 138^{+}$cells increased significantly at 6 days post infection, and then dropped to normal level later until day 14 post infection (Figure 2). In mice, CD38 is expressed on all naïve B cells but is down-regulated on isotype-switched B cells from germinal centers, foci of antibody-forming cells and mature plasma cells [29]. In contrast, CD138 is a cell surface heparan sulphate proteoglycan that is highly expressed by plasma cells.

\begin{tabular}{|c|c|c|c|c|c|}
\hline \multirow[t]{2}{*}{ Items } & & \multicolumn{2}{|c|}{ Macrophages } & \multicolumn{2}{|c|}{ Neutrophils } \\
\hline & & $\mathrm{R}^{2}$ & $p$ & $\mathrm{R}^{2}$ & $p$ \\
\hline \multirow[t]{2}{*}{ Lung } & $\lg G$ & 0.826 & $0.000^{* *}$ & 0.861 & $0.000^{* *}$ \\
\hline & $\lg A$ & 0.807 & $0.000^{* *}$ & 0.810 & $0.000^{* *}$ \\
\hline \multirow[t]{3}{*}{ Serum } & $\lg G$ & 0.844 & $0.000^{* *}$ & 0.909 & $0.000^{* *}$ \\
\hline & $\lg A$ & 0.230 & 0.280 & 0.323 & 0.124 \\
\hline & $\mathrm{HI}$ & 0.706 & $0.000^{* *}$ & 0.750 & $0.000^{* *}$ \\
\hline
\end{tabular}

${ }^{*} p<0.05,{ }^{* *} p<0.01$ correlation between antibodies and macrophages or neutrophils. 


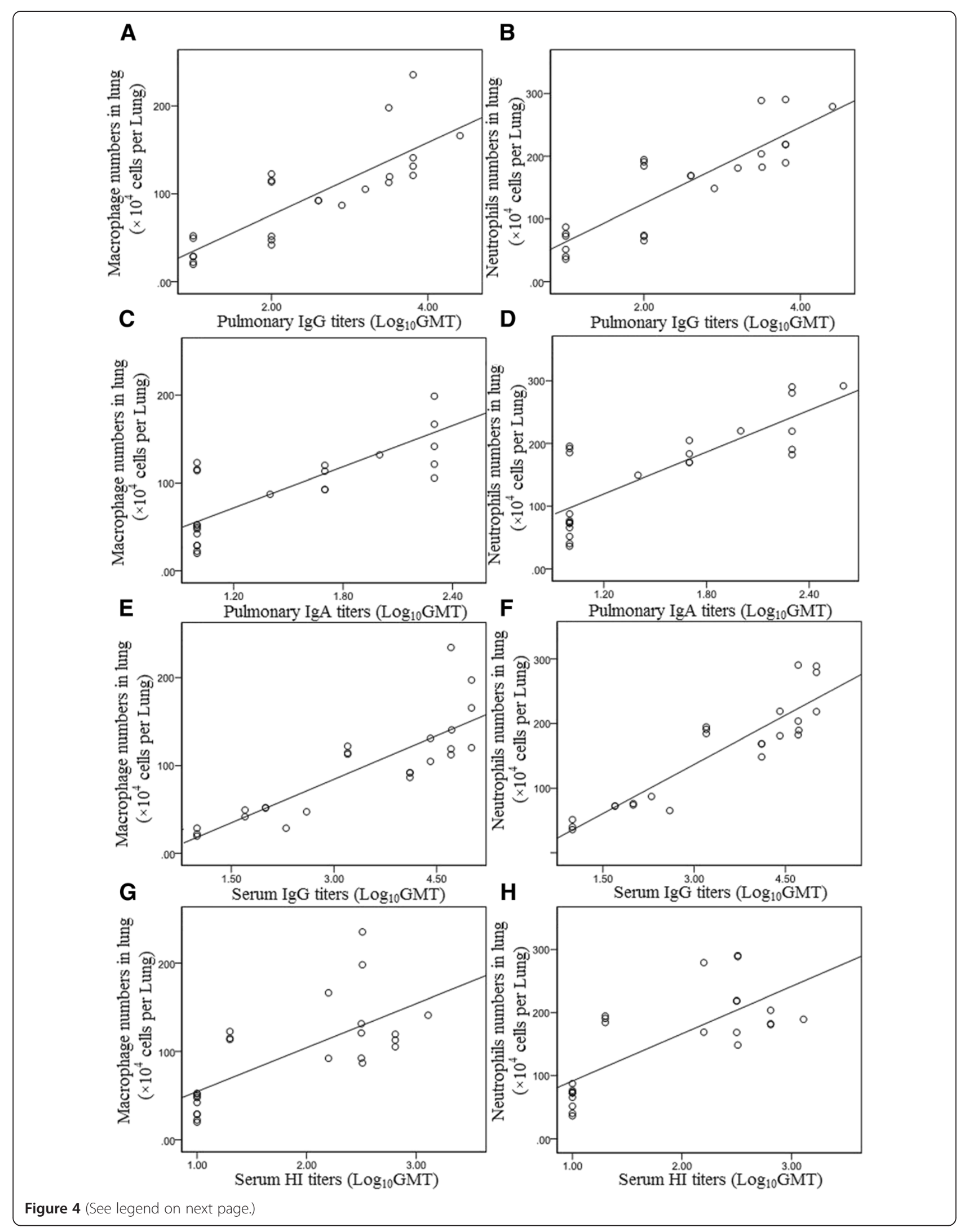


(See figure on previous page.)

Figure 4 Scatter plot of Table 1. (A) Scatter plot of macrophage numbers $\times 10^{4}$ per lung and pulmonary lgG titers of mice infected with A/PR/ $8 / 34$ (H1N1) influenza viruses; (B) Scatter plot of neutrophils numbers $\times 10^{4}$ per lung and pulmonary lgG titers of mice infected with A/PR/8/34 ( $\mathrm{H} 1 \mathrm{~N} 1$ ) influenza viruses; (C) Scatter plot of macrophage numbers $\times 10^{4}$ per lung and pulmonary lgA titers of mice infected with $A / P R / 8 / 34$ (H1N1) influenza viruses; (D) Scatter plot of neutrophils numbers $\times 10^{4}$ per lung and pulmonary lgA titers of mice infected with A/PR/8/34 (H1N1) influenza viruses; (E) Scatter plot of macrophage numbers $\times 10^{4}$ per lung and serum lgG titers of mice infected with A/PR/8/34 (H1N1) influenza viruses; (F) Scatter plot of neutrophils numbers $\times 10^{4}$ per lung and serum lgG titers of mice infected with A/PR/8/34 (H1N1) influenza viruses; (G) Scatter plot of macrophage numbers $\times 10^{4}$ per lung and serum $\mathrm{HI}$ titers of mice infected with A/PR/8/34 (H1N1) influenza viruses; (H) Scatter plot of neutrophils numbers $\times 10^{4}$ per lung and serum $\mathrm{HI}$ titers of mice infected with A/PR/8/34 (H1N1) influenza viruses.

\section{Comparing the kinetics of pulmonary macrophages and} neutrophils with lung antibody responses in lung and serum of mice with fatal influenza $A$ virus infection

The dynamics of lung antibody levels were similar with the kinetics of lung macrophage and neutrophils frequencies (Figure 3). A correlation analysis showed that both macrophages and neutrophils closely correlated with IgG and IgA antibody responses in lungs $\left(R^{2}=\right.$ 0.826, $p=0.000$ and $R^{2}=0.861, p=0.000, R^{2}=0.807, p=$ 0.000 and $R^{2}=0.810, p=0.000$, respectively), and serum IgG, and $\mathrm{HI}$ antibody responses $\left(R^{2}=0.844, p=0.000\right.$ and $R^{2}=0.909, p=0.000, R^{2}=0.706, p=0.000$ and $R^{2}=$ $0.750, p=0.000$, respectively), but no correlation with serum IgA antibody $\left(R^{2}=0.230, p=0.280\right.$ and $R^{2}=0.323$, $p=0.124$, respectively) (Table 1 ). The scatter plots for the significant correlations see Figure 4.

\section{Correlations between viral load with pulmonary macrophages, neutrophils and antibody responses in lungs and serum}

The influenza virus titer began to decrease in the late stage of infection. As indicated in Figure 3, at day 12 and day 14 post infection the virus significantly decreased. To measure whether the increased macrophage and neutrophil frequencies were correlated with the decrease of viral load, a correlation analysis was performed. Results showed that there was a significant negative correlation between macrophage or neutrophils and viral

Table 2 Correlation analysis between viral load and pulmonary macrophages, neutrophils and antibody levels in serum and lungs in fatal mice infection

\begin{tabular}{lccc}
\hline Items & \multicolumn{2}{c}{ Viral load } \\
\cline { 3 - 4 } & & $\mathbf{R}^{\mathbf{2}}$ & $\boldsymbol{p}$ \\
\hline Macrophages & -0.751 & $0.000^{* *}$ \\
Neutrophils & & -0.693 & $0.000^{* *}$ \\
Lung & $\lg$ & -0.713 & $0.000^{* *}$ \\
& $\lg \mathrm{A}$ & -0.775 & $0.000^{* *}$ \\
Serum & $\operatorname{lgG}$ & -0.695 & $0.000^{* *}$ \\
& $\operatorname{lgA}$ & 0.225 & 0.327 \\
& $\mathrm{HI}$ & -0.637 & $0.002^{* *}$ \\
& &
\end{tabular}

${ }^{*} p<0.05,{ }^{* *} p<0.01$ correlation between antibody and viral load and macrophages, neutrophils and antibodies in fatal mice infection. load in lungs $\left(R^{2}=-0.751, p=0.000\right.$ and $R^{2}=-0.693 p=$ 0.000 , respectively) (Table 2 ). In addition, the decreased viral loads significantly correlated with increased IgG antibody level both in the lungs and sera $\left(R^{2}=-0.713, p=\right.$ 0.000 , and $R^{2}=-0.695, p=0.000$, respectively), and with the increased lung IgA and sera HI antibody $\left(R^{2}=-0.775\right.$, $p=0.000$ and $R^{2}=-0.637, p=0.002$, respectively) (Figure 3, Table 2). The scatter plots for the significant correlations see Figure 5. The decreased viral load showed no significant correlation with other immune cells (data not shown).

\section{Kinetics of cytokines in the lung}

Three cytokines (IL-6, IFN- $\gamma$, IL-10) increased significantly in the early stage of infection, but they all decreased to control levels at the late stage. The earliest increased cytokine was IL-6, which increased at day 2 post-infection. Both IFN- $\gamma$ and IL-10 significantly increased at day 6 post-infection, but all rapidly decreased to the control level later on. However, IL-17 and IL-4, showed a significant decreased level during the infection, especially after 2 days post infection (Figure 6).

\section{Correlations of cytokine responses with macrophages, neutrophils and viral load in lungs}

The dynamics of pulmonary cytokine response showed the different increase patterns. Statistical analysis showed that the decreased of IL-6 had a close relation with that of macrophages, neutrophils and the decrease of viral loads $\left(R^{2}=-0.754, p=0.000, R^{2}=-0.782, p=0.000\right.$ and $R^{2}=$ $0.759, p=0.000$, respectively) (Table 3 ). The significant negative correlations of IL- 4 with macrophages and neutrophils and viral load were also observed $\left(R^{2}=-0.612\right.$, $p=0.000, R^{2}=-0.673, p=0.000$ and $R^{2}=-0.592, p=0.000$, respectively), while no close correlation was observed between other cytokines and cells $(P>0.05)$ (Table 3$)$. The scatter plots for the significant correlations see Figure 7.

\section{Discussion}

Macrophages and neutrophils have a complicated role in protecting against high-dose lethal infection of influenza A virus. In this study, the mice were fatally infected with $\mathrm{A} / \mathrm{PR} / 8 / 34$ (H1N1) influenza virus. We monitored the kinetics of the macrophages, neutrophils, $\mathrm{CD} 4^{+} \mathrm{T}$ cell, 


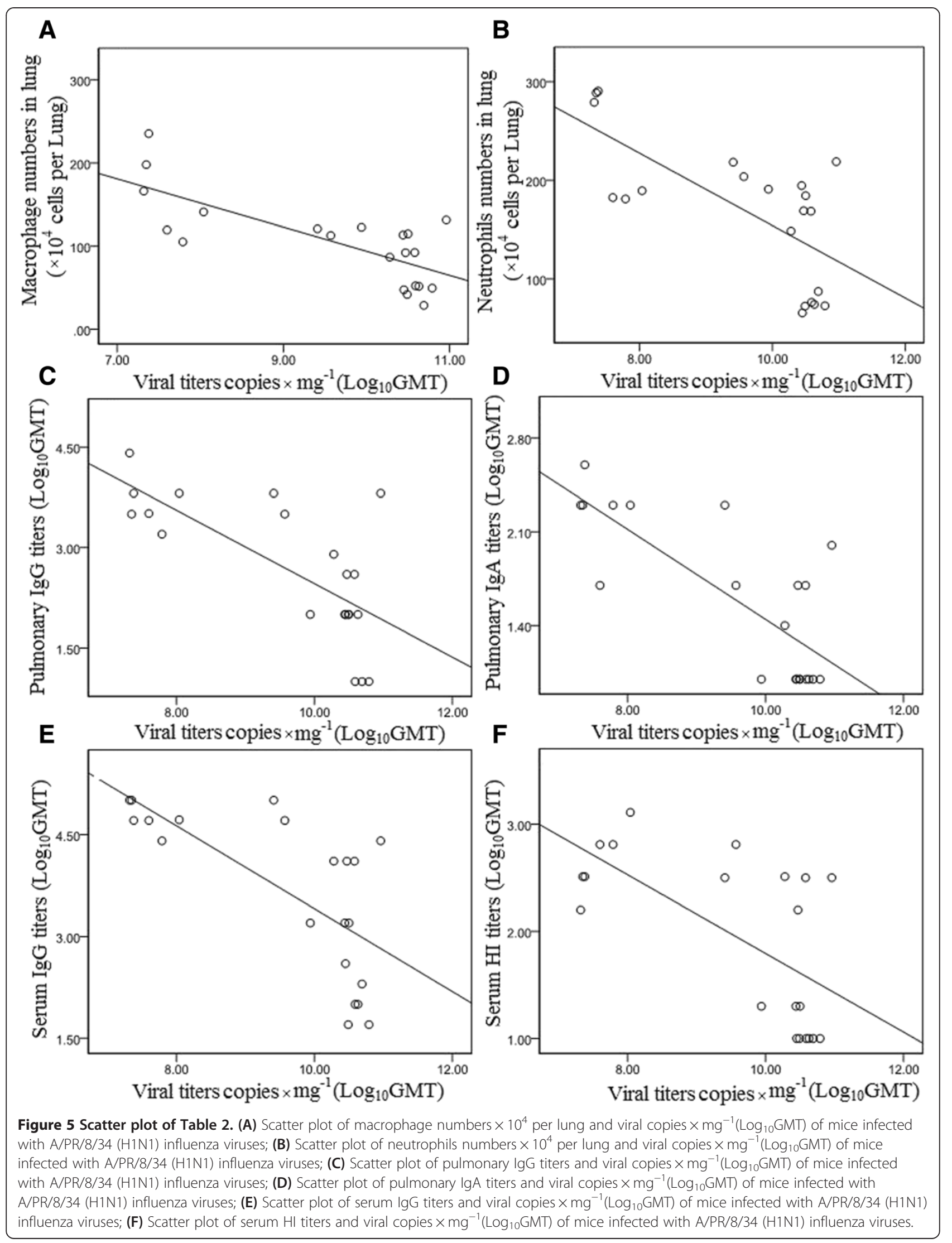




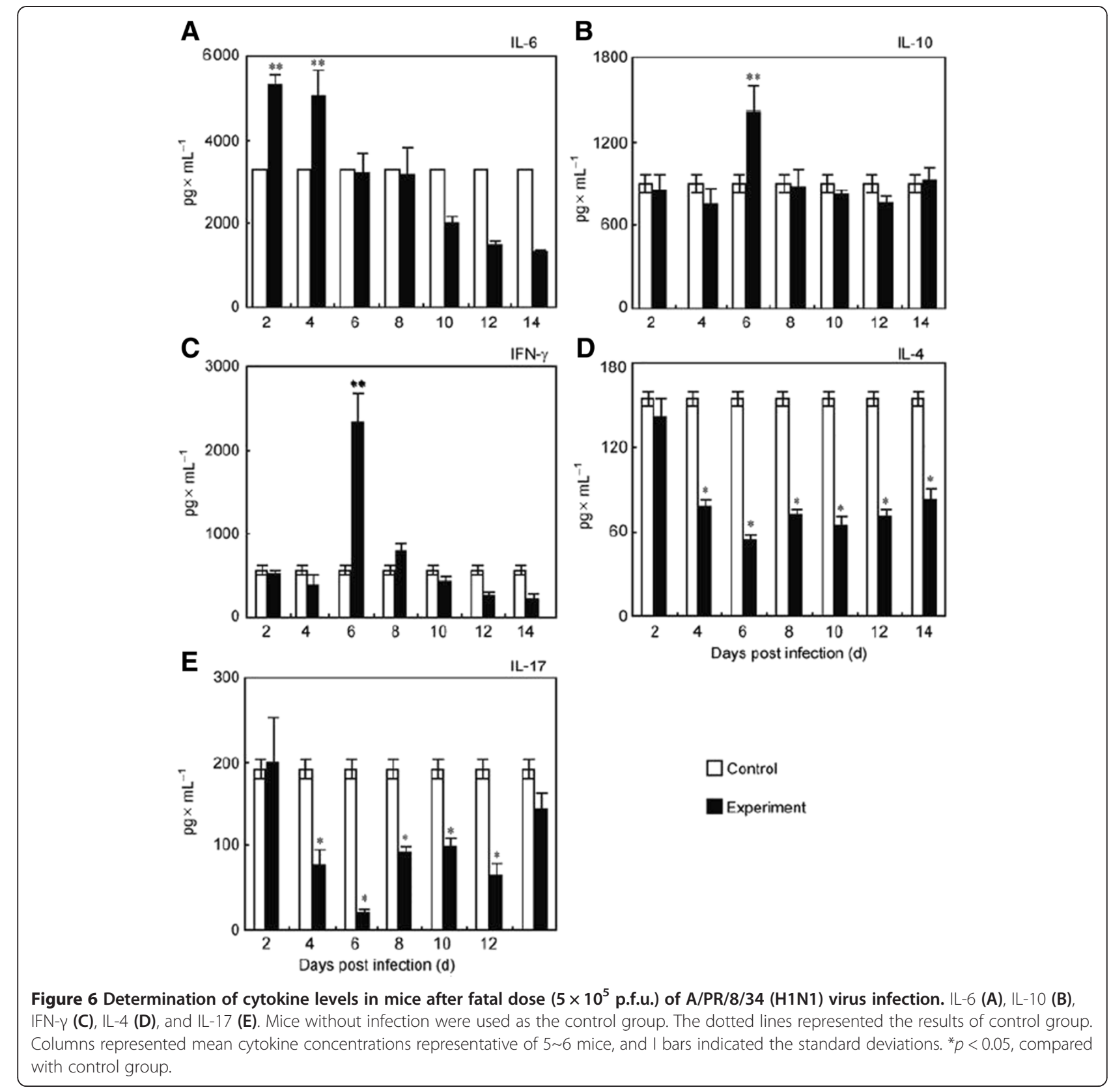

Table 3 Correlations among the cytokine responses, macrophages, neutrophils and viral load in lungs in fatal mice infection

\begin{tabular}{|c|c|c|c|c|c|c|}
\hline \multirow[t]{2}{*}{ Cytokines } & \multicolumn{2}{|c|}{ Macrophages } & \multicolumn{2}{|c|}{ Neutrophils } & \multicolumn{2}{|c|}{ Viral load } \\
\hline & $\overline{R^{2}}$ & $p$ & $\overline{R^{2}}$ & $p$ & $\overline{R^{2}}$ & $p$ \\
\hline IL-6 & -0.754 & $0.000^{* *}$ & -0.782 & $0.000^{* *}$ & 0.759 & $0.000^{* *}$ \\
\hline $\mid L-4$ & -0.612 & $0.000^{* *}$ & -0.673 & $0.000^{* *}$ & -0.592 & $0.002^{* *}$ \\
\hline IFN- $\gamma$ & 0.060 & 0.780 & 0.119 & 0.581 & 0.310 & 0.171 \\
\hline IL-10 & 0.143 & 0.504 & 0.196 & 0.360 & 0.150 & 0.516 \\
\hline IL-17 & -0.235 & 0.268 & -0.250 & 0.238 & -0.048 & 0.837 \\
\hline
\end{tabular}

${ }^{*} p<0.05,{ }^{* *} p<0.01$ correlation between cytokines and macrophages, neutrophils and viral load.
$\mathrm{CD}^{+}{ }^{+} \mathrm{T}$ cell, $\mathrm{CD} 138^{+}$cell and $\mathrm{CD}^{+} 8^{+}$cell in the lungs during the viral infection. We found that macrophages and neutrophils accumulated in the lungs, both in the early and late phases of the virus infection. The decreased viral load significantly correlated with the increased macrophages and neutrophils, and antibody levels both in the lung and serum. The present study suggests that macrophages and neutrophils and the antibody responses both have an important role in eliminating of influenza virus locally.

As to both induce the fatal immunopathology in the lung and ensure the enough mice to survive for further experiment, we at first established an appropriate dose 


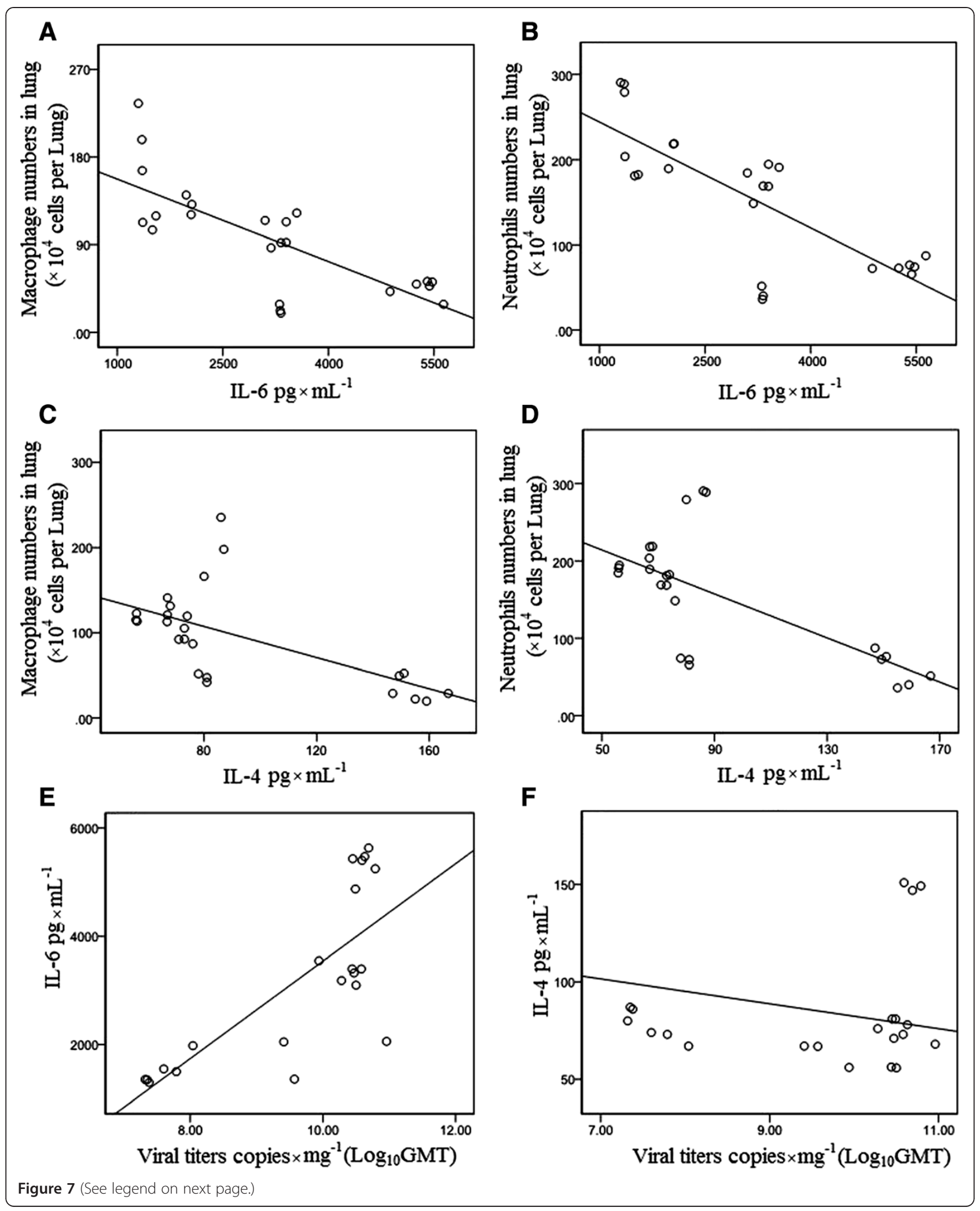

of virus. We found $5 \times 10^{5}$ p.f.u. viruses had a decreased lethality in mice than the dose of $5 \times 10^{4}$ and $5 \times 10^{3}$ p.f. u. The reason might be that $5 \times 10^{4}$ p.f.u. could replicate more efficiently than $5 \times 10^{5}$ p.f.u.viruses in the upper respiratory tract, thus came higher lethality. We understood it was not common for other influenza viruses, 
(See figure on previous page.)

Figure 7 Scatter plot of Table 3. (A) Scatter plot of macrophage numbers $\times 10^{4}$ per lung and pulmonary IL-6 pg $\times \mathrm{mL}^{-1}$ of mice infected with $\mathrm{A} / \mathrm{PR} / 8 / 34$ (H1N1) influenza viruses; (B) Scatter plot of neutrophils numbers $\times 10^{4}$ per lung and pulmonary $\mathrm{LL}-6 \mathrm{pg} \times \mathrm{mL}^{-1}$ of mice infected with $\mathrm{A} / \mathrm{PR} / 8 / 34$ (H1N1) influenza viruses; (C) Scatter plot of macrophage numbers $\times 10^{4}$ per lung and IL-4 pg $\times \mathrm{mL}^{-1}$ of mice infected with $\mathrm{A} / \mathrm{PR} / 8 / 34$ (H1N1) influenza viruses (D) Scatter plot of neutrophils numbers $\times 10^{4}$ per lung and pulmonary $\mathrm{IL}-4 \mathrm{pg} \times \mathrm{mL}^{-1}$ of mice infected with $\mathrm{A} / \mathrm{PR} / 8 / 34$ (H1N1) influenza viruses; (E) Scatter plot of pulmonary lL-6 pg $\times \mathrm{mL}^{-1}$ and viral copies $\times \mathrm{mg}^{-1}\left(\mathrm{Log}_{10} \mathrm{GMT}\right)$ of mice infected with A/PR/8/34 (H1N1) influenza viruses; (F) Scatter plot of pulmonary $\mathrm{LL}-4 \mathrm{pg} \times \mathrm{mL}^{-1}$ and viral copies $\times \mathrm{mg}^{-1}\left(\mathrm{Log}_{10} \mathrm{GMT}\right)$ of mice infected with A/PR/8/34 (H1N1) influenza viruses.

and did not know whether it was correlated with the characteristic of PR8 as a mouse-adapted virus strain, although there was no published article reported the similar experiments.

Observations from de Jong et al. [30] supported the presence of an inflammatory response role in the pathogenesis of human $\mathrm{H} 5 \mathrm{~N} 1$ disease. In addition, postmortem studies in H5N1-infected individuals have not shown predominance of lymphocytes, but rather of macrophages, in pulmonary in-filtrates [31]. Although $\mathrm{CD} 4^{+} \mathrm{T}$ cell and $\mathrm{CD}^{+} \mathrm{T}$ cells also have a protective effect during the pathogen infection, especially during high pathogenic avian influenza viruses infection, the protective was also seen in the absence of all $\mathrm{T}$ and $\mathrm{B}$ cells as well as in the depletion of neutrophils or NK cells [32]. Whereas, depletion of innate lymphoid cells resulted in loss of airway epithelial integrity, diminished lung function and impaired airway remodeling [33]. Furthermore, study by Tate MD [34] showed that neutrophil depletion early after infection with influenza virus did not alter influenza virus-derived antigen presentation or naïve $\mathrm{CD} 8^{+} \mathrm{T}$-cell expansion in the secondary lymphoid organs and of trafficking of virusspecific $\mathrm{CD} 8^{+} \mathrm{T}$ cells into the infected pulmonary airways. Instead early neutrophils reduced both the overall magnitude of influenza virus-specific $\mathrm{CD} 8^{+} \mathrm{T}$ cells, together with impaired cytokine production and cytotoxic effector function. In contrast to that, the depletion of macrophages lead to the death of all of the mice even those challenged with a sublethal dose of virus [32], therefore it was impossible to evaluate the protective effect with removal of macrophages.

The accumulation of macrophages and neutrophils in the early phase also have been observed in mice [12] and chickens [35] fatally infected with influenza viruses. In this study, we observed a significant increased frequency of macrophages in the lung at day 4 post infection. We also evaluated the kinetics of macrophages and neutrophils in the late phase infection. When the viral load in the lung significantly decreased at day 10 post infection, the macrophage and neutrophil frequencies were maintained at high levels. Previous research also found that in the late recovery phase, macrophage and neutrophil inhibition led to a marked delay in the elimination of the virus. All these observations suggest that macrophages and neutrophils may contribute to late-phase clearance of influenza viruses [36]. Previous evidence has suggested that influenza A virus infected cells are subjected to apoptosis-dependent phagocytosis and degrade together with the invading virus within phagocytes. It has been speculated that macrophages and neutrophils accumulate in lung tissues and maximize the efficiency of the phagocytic elimination of infected cells [37].

IL-6 secretion significantly increased early at day 2 post-infection and quickly decreased to the level of the control, suggesting a correlation with the accumulation of macrophage. Suzuki [35] also reported that IL-6 mRNA was quickly induced at $24 \mathrm{~h}$ post-infection, but $8 \mathrm{~h}$ later, mRNA levels became dramatically lower. IL- 6 concentrations were significantly correlated to the symptoms and signs of influenza A infection in humans $[14,15]$. Elevated IL- 6 values have been detected in HPAI H5N1 influenza virus infected human cells and mice [16-19,38]. As a multifunctional cytokine expressed by both lymphoid and non-lymphoid cells [39], IL-6 has a central role in elucidating an innate immune response and directing the transition from innate to adaptive immunity [40]. However, IL-6 cytokine inhibition does not directly protect against death from lethal H5N1 influenza virus infection [20].

Our study evaluated kinetic responses and correlation of several types of immune cells, cytokines and antibodies in a mouse model, but did not reveal how they were orchestrated in the virus clearance. Further evaluation of the cooperation between macrophages, neutrophils and antibody responses in eliminating the virus with fatal infection is needed.

\section{Competing interests}

The authors declare that they have no competing interests.

\section{Author's contributions}

$J \mathrm{~L}, \mathrm{YHH}, \mathrm{XLW}, \mathrm{QSJ}$ and NJ conceived and designed the study. Experiments were performed by $J$, YHH, DW, and AFL. Data were analysed by $J$, AJ, AML, YFW, and NJ. JL and NJ participated in its design and coordination and helped to draft the manuscript. All authors read and approved the final manuscript.

\section{Acknowledgement}

We would like to thank Mr. Shijia-Pei (Cellular Technology Ltd.) for ELISPOT reading and Liangyan-Zhang for Flow cytometry measurement. This study was supported by the grants of National Natural Science Foundation of China (81172130, 81301662). 


\section{Author details}

The Second Artillery General Hospital, PLA, 16 Xinjiekouwai Street, Xicheng District, Beijing 100088, China. ${ }^{2}$ State Key Laboratory of Pathogen and Biosecurity, Beijing Institute of Microbiology and Epidemiology, 20 Dong-Da Street, Fengtai District, Beijing 100071, P.R. China. ${ }^{3}$ Department of Biochemistry, The University of Hong Kong, Pokfulam, Hong Kong, China.

Received: 13 November 2013 Accepted: 13 March 2014

Published: 26 March 2014

\section{References}

1. $C D C$ : Emergence of avian influenza $A(H 7 N 9)$ virus causing severe human illness - China, February-April 2013. MMWR Morb Mortal Wkly 2013, 62:366-371

2. Wain-Hobson S: Pandemic influenza viruses: time to recognize our inability to predict the unpredictable and stop dangerous gain-offunction experiments. EMBO Mol Med 2013, 5:1637-1641.

3. Li W, Shi W, Qiao H, Ho SY, Luo A, Zhang Y, Zhu C: Positive selection on hemagglutinin and neuraminidase genes of H1N1 influenza viruses. Virol J 2011, 8:183.

4. Reid AH, Taubenberger JK, Fanning TG: The 1918 Spanish influenza: integrating history and biology. Microbes Infect 2001, 3:81-87.

5. Seynaeve G: Influenza pandemic: a perspective. Prehosp Disaster Med 2009, 24:473-477.

6. Schnitzler SU, Schnitzler P: An update on swine-origin influenza virus A/H1N1: a review. Virus Genes 2009, 39:279-292.

7. Dixit R, Khandaker G, Ilgoutz S, Rashid H, Booy R: Emergence of oseltamivir resistance: control and management of influenza before, during and after the pandemic. Infect Disord Drug Targets 2013, 13:34-45.

8. World Health Organization: Number of confirmed human cases of avian influenza A ( H7N9) reported to WHO. WHO/HO; 2013.

9. Kobasa D, Jones SM, Shinya K, Kash JC, Copps J, Ebihara H, Hatta Y, Kim JH Halfmann P, Hatta M, Kim JH, Halfmann P. Hatta M, Feldmann F, Alimonti JB, Fernando L, Li Y, Katze MG, Feldmann H, Kawaoka Y: Aberrant innate immune response in lethal infection of macaques with the 1918 influenza virus. Nature 2007, 445:319-323.

10. Nakajima N, Van Tin N, Sato Y, Thach HN, Katano H, Diep PH, Kumasaka T, Thuy NT, Hasegawa H, San LT, Kawachi S, Liem NT, Suzuki K, Sata T: Pathological study of archival lung tissues from five fatal cases of avian H5N1 influenza in Vietnam. Mod Pathol 2013, 26:357-369.

11. Szretter KJ, Gangappa S, Belser JA, Zeng H, Chen H, Matsuoka Y, Sambhara S, Swayne DE, Tumpey TM, Katz JM: Early control of H5N1 influenza virus replication by the type I interferon response in mice. J Virol 2009, 83:5825-5834.

12. Perrone LA, Plowden JK, Garcia-Sastre A, Katz JM, Tumpey TM: H5N1 and 1918 pandemic influenza virus infection results in early and excessive infiltration of macrophages and neutrophils in the lungs of mice. PLoS Pathog 2008, 4:e1000115.

13. Tumpey TM, Garcia-Sastre A, Taubenberger JK, Palese P, Swayne DE, Pantin-Jackwood MJ, Schultz-Cherry S, Solorzano A, Van Rooijen N, Katz JM Basler CF: Pathogenicity of influenza viruses with genes from the 1918 pandemic virus: functional roles of alveolar macrophages and neutrophils in limiting virus replication and mortality in mice. J Virol 2005, 79:14933-14944

14. Reemers SS, Van Leenen D, Koerkamp MJ, Van Haarlem D, van de Haar P, Van Eden W, Vervelde L: Early host responses to avian influenza A virus are prolonged and enhanced at transcriptional level depending on maturation of the immune system. Mol Immunol 2010, 47:1675-1685.

15. To KK, Hung IF, Li IW, Lee KL, Koo CK, Yan WW, Liu R, Ho KY, Chu KH, Watt CL, Luk WK, Lai KY, Chow FL, Mok T, Buckley T, Chan JF, Wong SS, Zheng B, Chen H, Lau CC, Tse H, Cheng VC, Chan KH, Yuen KY: Delayed clearance of viral load and marked cytokine activation in severe cases of pandemic H1N1 2009 influenza virus infection. Clin Infect Dis 2010, 50:850-859.

16. Cheng $X, X u$ Q, Song $E$, Yang $C F$, Kemble $G$, Jin $H$ : The hemagglutinin protein of influenza A/Vietnam/1203/2004 (H5N1) contributes to hyperinduction of proinflammatory cytokines in human epithelial cells. Virology 2010, 406:28-36.

17. Geiler J, Michaelis M, Sithisarn P, Cinatl J Jr: Comparison of pro-inflammatory cytokine expression and cellular signal transduction in human macrophages infected with different influenza A viruses. Med Microbiol Immunol 2011, 200:53-60.
18. Ng YP, Lee SM, Cheung TK, Nicholls JM, Peiris JS, Ip NY: Avian influenza $\mathrm{H} 5 \mathrm{~N} 1$ virus induces cytopathy and proinflammatory cytokine responses in human astrocytic and neuronal cell lines. Neuroscience 2010, 168:613-623.

19. Song BM, Kang YM, Kim HS, Seo SH: Induction of inflammatory cytokines and toll-like receptors in human normal respiratory epithelial cells infected with seasonal H1N1, 2009 pandemic H1N1, seasonal H3N2, and highly pathogenic H5N1 influenza virus. Viral Immunol 2011, 24:179-187.

20. Salomon R, Hoffmann E, Webster RG: Inhibition of the cytokine response does not protect against lethal H5N1 influenza infection. Proc Natl Acad Sci U S A 2007, 104:12479-12481.

21. Yetter RA, Lehrer S, Ramphal R, Small PA Jr: Outcome of influenza infection: effect of site of initial infection and heterotypic immunity. Infect Immun 1980, 29:654-662.

22. Loosli CG, Stinson SF, Ryan DP, Hertweck MS, Hardy JD, Serebrin R: The destruction of type 2 pneumocytes by airborne influenza PR8-A virus; its effect on surfactant and lecithin content of the pneumonic lesions of mice. Chest 1975, 67:75-14S.

23. Harvey R, Guilfoyle KA, Roseby S, Robertson JS, Engelhardt OG: Improved antigen yield in pandemic H1N1 (2009) candidate vaccine viruses with chimeric hemagglutinin molecules. J Virol 2011, 85:6086-6090.

24. He Q, Martinez-Sobrido L, Eko FO, Palese P, Garcia-Sastre A, Lyn D, Okenu D, Bandea C, Ananaba GA, Black CM, Igietseme JU: Live-attenuated influenza viruses as delivery vectors for Chlamydia vaccines. Immunology 2007, 122:28-37.

25. Song JM, Lee $Y J$, Jeong OM, Kang HM, Kim HR, Kwon JH, Kim JH, Seong BL, Kim YJ: Generation and evaluation of reassortant influenza vaccines made by reverse genetics for H9N2 avian influenza in Korea. Vet Microbiol 2008, 130:268-276.

26. Yang C, Skiena S, Futcher B, Mueller S, Wimmer E: Deliberate reduction of hemagglutinin and neuraminidase expression of influenza virus leads to an ultraprotective live vaccine in mice. Proc Natl Acad Sci U S A 2013, 110:9481-9486.

27. Jelley-Gibbs DM, Dibble JP, Brown DM, Strutt TM, McKinstry KK, Swain SL: Persistent depots of influenza antigen fail to induce a cytotoxic CD8 T cell response. J Immunol 2007, 178:7563-7570.

28. Jia N, Li C, Liu YX, Richardus JH, Feng D, Yang $H$, Dang RL, Ma YH, Xu XN, Cao WC: Lower cellular immune responses to influenza $A(H 3 N 2)$ in the elderly. J Med Virol 2009, 81:1471-1476.

29. Shapiro-Shelef M, Calame K: Regulation of plasma-cell development. Nat Rev Immunol 2005, 5:230-242.

30. De Jong MD, Simmons CP, Thanh TT, Hien VM, Smith GJ, Chau TN, Hoang DM, Chau NV, Khanh TH, Dong VC, Qui PT, Cam BV, Ha do Q, Guan Y, Peiris JS, Chinh NT, Hien TT, Farrar J: Fatal outcome of human influenza $A$ (H5N1) is associated with high viral load and hypercytokinemia. Nat Med 2006, 12:1203-1207.

31. Peiris JS, Yu WC, Leung CW, Cheung CY, Ng WF, Nicholls JM, Ng TK, Chan KH, Lai ST, Lim WL, Yuen KY, Guan Y: Re-emergence of fatal human influenza A subtype H5N1 disease. Lancet 2004, 363:617-619.

32. Hamada H, Bassity E, Flies A, Strutt TM, Garcia-Hernandez Mde L, McKinstry KK, Zou T, Swain SL, Dutton RW: Multiple redundant effector mechanisms of CD8+ T cells protect against influenza infection. J Immunol 2014, 190:296-306.

33. Monticelli LA, Sonnenberg GF, Abt MC, Alenghat T, Ziegler CG, Doering TA Angelosanto JM, Laidlaw BJ, Yang CY, Sathaliyawala T, Kubota M, Turner D, Diamond JM, Goldrath AW, Farber DL, Collman RG, Wherry EJ, Artis D: Innate lymphoid cells promote lung-tissue homeostasis after infection with influenza virus. Nat Immunol 2011, 12:1045-1054

34. Tate MD, Brooks AG, Reading PC, Mintern JD: Neutrophils sustain effective CD8(+) T-cell responses in the respiratory tract following influenza infection. Immunol Cell Biol 2012, 90:197-205.

35. Suzuki K, Okada H, Itoh T, Tada T, Mase M, Nakamura K, Kubo M, Tsukamoto K: Association of increased pathogenicity of Asian H5N1 highly pathogenic avian influenza viruses in chickens with highly efficient viral replication accompanied by early destruction of innate immune responses. J Virol 2009, 83:7475-7486.

36. Fujisawa $\mathrm{H}$ : Neutrophils play an essential role in cooperation with antibody in both protection against and recovery from pulmonary infection with influenza virus in mice. J Virol 2008, 82:2772-2783.

37. Hashimoto Y, Moki T, Takizawa T, Shiratsuchi A, Nakanishi Y: Evidence for phagocytosis of influenza virus-infected, apoptotic cells by neutrophils and macrophages in mice. J Immunol 2007, 178:2448-2457. 
38. Cheung CY, Poon LL, Lau AS, Luk W, Lau YL, Shortridge KF, Gordon S, Guan $Y$, Peiris JS: Induction of proinflammatory cytokines in human macrophages by influenza $A(H 5 N 1)$ viruses: a mechanism for the unusual severity of human disease? Lancet 2002, 360:1831-1837.

39. Kishimoto T: IL-6: from its discovery to clinical applications. Int Immunol 2010, 22:347-352.

40. Lauder SN, Jones E, Smart K, Bloom A, Williams AS, Hindley JP, Ondondo B, Taylor PR, Clement M, Fielding C, Godkin AJ, Jones SA, Gallimore AM: Interleukin-6 limits influenza-induced inflammation and protects against fatal lung pathology. Eur J Immunol 2013, 43:2613-2625.

doi:10.1186/1743-422X-11-57

Cite this article as: Lv et al:: Kinetics of pulmonary immune cells, antibody responses and their correlations with the viral clearance of influenza A fatal infection in mice. Virology Journal 2014 11:57.

\section{Submit your next manuscript to BioMed Central and take full advantage of:}

- Convenient online submission

- Thorough peer review

- No space constraints or color figure charges

- Immediate publication on acceptance

- Inclusion in PubMed, CAS, Scopus and Google Scholar

- Research which is freely available for redistribution 